\title{
Marx and Keynes: from exploitation to employment
}

\author{
Fritz Helmedag* \\ Economics Department, Chemnitz University of Technology, Germany
}

\begin{abstract}
Marx's and Keynes's analyses of capitalism complement each other well. In a largely general model including the public sector and international trade it is shown that the labour theory of value provides a sound foundation to reveal the factors influencing employment. Workers buy 'necessaries' out of their disposable wages from an integrated basic sector, whereas the 'luxury' division's revenues spring from other sources of income. In order to maximize profits, the wage-good industry controls the level of unit labour costs. Ultimately, effective demand governs the volume of work. On this basis, implications for economic policy are outlined.
\end{abstract}

Keywords: employment, Marx, Keynes, surplus value

JEL codes: $E 11, E 12, E 24$

\section{SURPLUS VALUE AND THE RATE OF PROFIT}

The essence of this article is that the great economic thinkers mentioned in the title make a good couple, not only regarding their exposure of capitalism's malfunctions but also, and more importantly, from an analytical point of view. In fact, the labour theory of value (Marx's approach) provides a firm basis to inquire into the determinants of employment (Keynes's concern). First, let us take a glance at the complaints advanced by our protagonists against the prevalent mode of production.

Until his death in 1883, Karl Marx experienced the excesses of 'Manchester capitalism'. The miserable living conditions of the working poor at that time raised the later so-called 'Social Question'. Correspondingly, in Das Kapital one reads:

Accumulation of riches at one pole is ... at the same time accumulation of misery, agony of toil, slavery, ignorance, brutality, mental degradation at the opposite pole, i. e., on the side of the class that produces its own product in the form of capital. (Marx 1867 [1977]: 675, author's translation)

John Maynard Keynes, born in 1883, witnessed the Great Depression in the early 1930s, when millions of unemployed people became destitute. In The General Theory he uttered his fundamental criticism against the prevailing social evils:

The outstanding faults of the economic society in which we live are its failure to provide for full employment and its arbitrary and inequitable distribution of wealth and incomes. (Keynes 1936 [1973]: 372)

* Chemnitz University of Technology, Economics Department, Thüringer Weg 7, D-09107 Chemnitz, Germany; email: f.helmedag@wirtschaft.tu-chemnitz.de.

Received 13 October 2018, accepted 22 January 2019 
Marx and Keynes wanted to uncover the causes for the serious deficits of modern market economies. To be sure, Marx predicted the inevitable demise of the bourgeois regime, whereas Keynes considered himself rather as a saviour of the system. The 'doctor at the sickbed of capitalism', as he was sometimes called, even predicted that the social order would have good prospects in the distant future (Keynes 1930 [1972]). In spite of these differences, the present study reveals in a largely general setting that there is a close connection between the investigations of Marx and Keynes. The synthesis of both inquiries yields deep insights into the modus operandi of the contemporary economy. Using only necessary complexity, the model presented below not only features wage and profit earners, but also international trade and the public sector. The derived results are in accordance with the 'heroes' of this paper. Consequently, the findings also darken the hope that the frequently invoked self-regulating forces of laissez-faire alone change still deplorable grievances for the better.

Marx's scrutiny of capitalism is based on the labour theory of value, serving to identify 'exploitation' as an essential trait beneath its surface. He shared the classical subsistence wage hypothesis to the effect that the pay only suffices to acquire 'necessaries' for the reproduction of labour-power including certain historical and cultural needs (see Marx 1867 [1977]: 185). ${ }^{1}$ The surplus product as the physical substance of profit is materialized in commodities which exceed the wage basket. Against this setting it is sensible to separate the whole output in two components. Incidentally, this procedure was common practice in classical political economy. Adam Smith (1776 [1981]: 180) expresses this fundamental idea as follows:

$[\mathrm{W}]$ hen ... the labour of one family can provide food for two, the labour of half the society becomes sufficient to provide food for the whole. The other half ... can be employed in providing other things .... .

Likewise, Ricardo (1815 [1951]) proceeded with his corn economy, ${ }^{3}$ and Marx's exemplary sectoral division of the economy can also be reduced to an integrated wage-good industry and the remainder of production (see Helmedag 2014). This view was also taken up by Pigou, when he distinguished in his unemployment theory between 'wagegoods' and 'other goods' (Pigou 1933 [1968]: 71); a segmentation which was approved by Keynes (1936 [1973]: 273), too. ${ }^{4}$

However, it would be misleading to characterize the workers' consumption in kind, hereafter alternatively labelled basic, necessary or primary commodities. Rather, it is decisive for an aggregation that the respective items are purchased out of wages. By contrast, nonwage income - for example, profits and tax revenues - finances the acquisition of 'luxuries', synonymously classified as secondary commodities, including investment and public goods.

Although it is not perceptible from looking at a tube of toothpaste whence the money came to acquire it, analytically the toothpaste falls into one of the two groups of goods (wage-goods or the remainder), depending on whether its procurement originated from pay or other revenues. The separation always refers to sources of proceeds and not to persons who indeed may receive earned as well as unearned income. In this vein, national accounting compiles the functional distribution by reporting the wage bill and the total remuneration from entrepreneurial activities and wealth.

1. The classical theory of value is presented at length in Helmedag (2018: 103ff).

2. Smith refers in a footnote to Pufendorf, Cantillon and Hume, who also adhered to this dichotomization.

3. For a detailed account of the model's properties, see Helmedag (2018: 121ff and 146ff).

4. On the difference between the 'true' and the textbook doctrine of Keynes, see Helmedag (2012a). 
The abstraction even goes one step further. By assumption, the elements in the groups of goods are homogeneous, so that a fictitious amount of basic or luxury products can be specified. Both imaginary sectors are run in a vertically integrated way, that is, all intermediate and capital goods are obtained from a supplier in the same division if not manufactured inhouse. Of course, the primary division provides commodities for all employees including the workforce in the secondary division. Although in reality no specific objects correspond to the virtual separation of production, it will be demonstrated that the bifurcation makes it possible to identify the determinants of employment and the effects of process innovations.

According to Marx, a uniform rate of exploitation characterizes equilibrium in capitalism. This ratio $(r)$ can be measured in time spans or in pecuniary units (see Helmedag 2012b). If $y$ denotes the mean nominal return of a labour hour and $w$ the corresponding compensation, in all firms the identical relation between surplus and remuneration reads:

$$
r=\frac{y-w}{w}=\frac{1-\frac{w}{y}}{\frac{w}{y}} .
$$

The numerator in the first fraction of equation (1) indicates the hourly profit contribution, a gross amount including all incomes which derive from entrepreneurial activities and wealth. This combined revenue comprises interest on invested capital, payments for raw materials, land rent and 'pure' profit.

Alternatively, $r$ also arises from the consideration of the basic good which is sold for a certain price $\left(p_{B}\right)$. The uniform nominal wage rate $(w)$ can be decomposed in a quantity of the wage-good $\left(w_{B}\right)$ times its money value: $w=w_{B} p_{B}$. Furthermore, let $v_{B}$ represent the total amount of working time embodied in the basic product. Now, instead of equation (1), the following expression holds:

$$
r=\frac{p_{B}-v_{B} w_{B} p_{B}}{v_{B} w_{B} p_{B}}=\frac{1-v_{B} w_{B}}{v_{B} w_{B}} .
$$

Equalizing the right-hand sides of the surplus ratios (1) and (2) gives the real unit labour costs $(b)$, a pure number, because dimensions cancel out: ${ }^{5}$

$$
h=v_{B} w_{B}=\frac{w}{y}<1
$$

In Marx's terminology, $v_{B} w_{B}$ corresponds to the 'value of labour power' or 'paid labour', a proportion informing us which part of his working time the labourer spends working for himself. Additionally, a surplus is generated under capitalistic conditions. Thus, the lessthan symbol in equation (3) applies, and assures a positive rate of exploitation (1) respectively (2). Furthermore, as a consequence of the model's structure, this percentage coincides with the rate of profit.

The profit factor $(1+r)$ reads:

$$
1+r=1+\frac{y-w}{w}=\frac{y}{w}=\frac{1}{h}=\frac{1}{v_{B} w_{B}}>1 .
$$

The reciprocal of the unit labour costs can be interpreted as the production- or core-price level, indicating how often the wage rate is included in the hourly yield. Adam Smith

5. However, the denominator of nominal unit labour costs, which are irrelevant in this examination, refers on the microeconomic level to a periodical output quantity, whereas from a macroeconomic perspective a quasi-physical benchmark is provided by deflated gross domestic product. 
called this term 'labour commanded' (see Smith 1776 [1981]: 47ff). This number specifies how many labour units can be hired in return for the sale of a commodity. Keynes also used the 'wage-unit' to exclude changes in the nominal pay from his theory: Sums of money are divided by the ordinary wage rate, thus transforming pecuniary values into labour quantities (see Keynes 1936 [1973]: 41).

\section{UNIT LABOUR COSTS AND SECTORAL PROFITS}

The average rate of fiscal charges levied on the gross wage bill $\left(t_{W}\right)$ includes direct and indirect taxes as well as the social security contributions. In order to calculate the effective burden, transfers like sickness benefits or rent subsidies are set off. Yet disposable income is not completely spent on home-made goods. One part of the available remuneration is diverted into savings $\left(s_{W}\right)$ and another share flows abroad to pay for imports $\left(m_{W}\right)$. Therefore, the propensity to consume out of disposable wages $\left(c_{W}\right)$ only refers to domestic demand. Analogous definitions apply for profits, symbolized by the subscript $P$. The parameters are subject to the following restrictions:

$$
\begin{array}{lll}
0 \leq t_{W}, s_{W}, m_{W}<1 & \text { and } & 0<c_{W}=1-s_{W}-m_{W}<1 \\
0 \leq t_{P}, s_{P}, m_{P}<1 & \text { and } & 0<c_{P}=1-s_{P}-m_{P}<1
\end{array}
$$

Sectoral gross profits - including rents for resources and interest on invested capital amount to the rate of profit $(r)$ times the vertically integrated wage sums in the basic industry $\left(W_{B}\right)$ and in the luxury division $\left(W_{X}\right)$, respectively. This approach is in accordance with the conception of Keynes:

I sympathise ... with the ... doctrine that everything is produced by labour, aided by what used to be called art and is now called technique, by natural resources which are free or cost a rent according to their scarcity or abundance, and by the results of past labour, embodied in assets, which also command a price according to their scarcity or abundance. It is preferable to regard labour ... as the sole factor of production ... (Keynes 1936 [1973]: 213f, emphases in original)

The difference between revenues and integrated labour costs constitutes profit. The gains of the wage-good sphere $\left(P_{B}\right)$ total to:

$$
P_{B}=r W_{B}=c_{W}\left(1-t_{W}\right)\left(W_{B}+W_{X}\right)-W_{B} .
$$

Among other things, the secondary division satisfies demand arising from aggregated autonomous expenditures $(A)$, based on discretionary spending decisions. These disbursements are independent of current earnings and encompass private net investments $(I)$ and exports adjusted for imported components expressed in local currency $(X)$. Besides, a budget deficit of the Treasury including social security $(D)$ has to be added, whereas a surplus would have a negative effect:

$$
A=I+X+D \text {. }
$$

Furthermore, the revenues in this sector are augmented by domestic demand from disposable profits plus the tax-funded services of the public sector; while credit-financed benefits are included in autonomous outlay. Subtracting the wage bill yields profits in the luxury division $\left(P_{X}\right)$ :

$$
P_{X}=r W_{X}=A+c_{P}\left(1-t_{P}\right) r\left(W_{B}+W_{X}\right)+\left(t_{W}+r t_{P}\right)\left(W_{B}+W_{X}\right)-W_{X} .
$$


From equation (6) and equation (8) labour costs in the basic industry are derived either depending on the profit rate $r$ or on unit labour costs $h$ :

$$
\begin{aligned}
W_{B} & =\frac{c_{W}\left(1-t_{W}\right) A}{(1+r)\left[r\left(1-c_{P}\right)\left(1-t_{P}\right)+\left(1-c_{W}\right)\left(1-t_{W}\right)\right]}= \\
& =\frac{h c_{W}\left(1-t_{W}\right) h A}{(1-h)\left(1-c_{P}\right)\left(1-t_{P}\right)+h\left(1-c_{W}\right)\left(1-t_{W}\right)} .
\end{aligned}
$$

The workers in the luxury division obtain:

$$
\begin{aligned}
W_{X} & =\frac{\left(r+1-c_{W}\left(1-t_{W}\right)\right) A}{(1+r)\left[r\left(1-c_{P}\right)\left(1-t_{P}\right)+\left(1-c_{W}\right)\left(1-t_{W}\right)\right]}= \\
& =\frac{\left[1-b c_{W}\left(1-t_{W}\right)\right] h A}{(1-h)\left(1-c_{P}\right)\left(1-t_{P}\right)+h\left(1-c_{W}\right)\left(1-t_{W}\right)} .
\end{aligned}
$$

At large, the workforce receives:

$$
\begin{aligned}
W_{B}+W_{X} & =\frac{A}{r\left(1-c_{P}\right)\left(1-t_{P}\right)+\left(1-c_{W}\right)\left(1-t_{W}\right)}= \\
& =\frac{h A}{(1-h)\left(1-c_{P}\right)\left(1-t_{P}\right)+h\left(1-c_{W}\right)\left(1-t_{W}\right)} .
\end{aligned}
$$

The first fraction in equation (11) straightforwardly shows that the total wage bill is negatively correlated with the profit rate. Then the opposite relation holds with respect to unit labour costs. ${ }^{6}$ Calculating the proportion between the sectoral compensations leads to:

$$
\frac{W_{B}}{W_{X}}=\frac{h c_{W}\left(1-t_{W}\right)}{1-h c_{W}\left(1-t_{W}\right)} .
$$

This ratio can be used to determine how the basic profit varies with labour costs in the luxury division:

$$
P_{B}=\frac{1-h}{h} W_{B}=\frac{1-h}{h} \frac{h c_{W}\left(1-t_{W}\right)}{1-h c_{W}\left(1-t_{W}\right)} W_{X}=\frac{(1-h) c_{W}\left(1-t_{W}\right)}{1-h c_{W}\left(1-t_{W}\right)} W_{X} .
$$

Equation (13) reveals that the basic sector has an ambiguous attitude towards remuneration: On the one hand, the division would prefer to pay the employees as little as possible in order to reduce costs. On the other hand, the surplus increases with a rising wage bill in the luxury segment, since part of it makes the cash tills ring in the primary sector.

Actually, there is always a profit maximum in the wage-good production because, according to Rolle's theorem, every continuously differentiable function has an optimum between two different roots. These preconditions apply for the basic industry. Starting from zero, rising

6. Obviously, autonomous demand $A$ has to be positive in order to avoid the collapse of the economy. Thus, a possible budget surplus of the public sector has to be smaller than net investments plus exports. 
unit labour costs cause an increase of gross profits in this sector up to a maximum at $b^{*}$. Then the surplus $P_{B}$ decreases and vanishes at $h=1$ :

$$
0<b^{*}=\frac{\left(1-c_{P}\right)\left(1-t_{P}\right)-\sqrt{\left(1-c_{P}\right)\left(1-t_{P}\right)\left(1-c_{W}\right)\left(1-t_{W}\right)}}{\left(1-c_{P}\right)\left(1-t_{P}\right)-\left(1-c_{W}\right)\left(1-t_{W}\right)}<1 .
$$

In addition to this level of paid labour, ${ }^{7}$ another value is of special interest. Setting the righthand side of equation (12) equal to 1 may result in unit labour costs $\hat{h}$, situated between 0.5 and 1 , where wages and profits in the sectors coincide:

$$
\frac{1}{2}<\hat{h}=\frac{1}{2 c_{W}\left(1-t_{W}\right)}<1 \quad \text { for } \quad 1>c_{W}\left(1-t_{W}\right)>\frac{1}{2} .
$$

Noticeably, this magnitude, which equalizes the incomes in the sectors, as well as the ratio between the wage sums (12), only hinges on the workers' domestic demand and their tax burden. In contrast, the corresponding parameters of the profit earners do not appear.

Figure 1 illustrates gross profit in the primary and secondary industry as functions of unit labour costs. The diagram is based on the following arbitrarily chosen specification: $A=1, c_{W}=0.75, t_{W}=0.1, c_{P}=0.5$ and $t_{P}=0.2$. In the present example the maximum gain in the wage-good division is reached before the profit curves intersect. ${ }^{8}$

Assuming all companies receive the same profit, then the quantity of enterprises in the sectors will adapt to the relation $P_{B} / P_{X}$. Though aggregated profits are higher in the luxury division up to the intersection of the profit curves, the greater quantity of firms

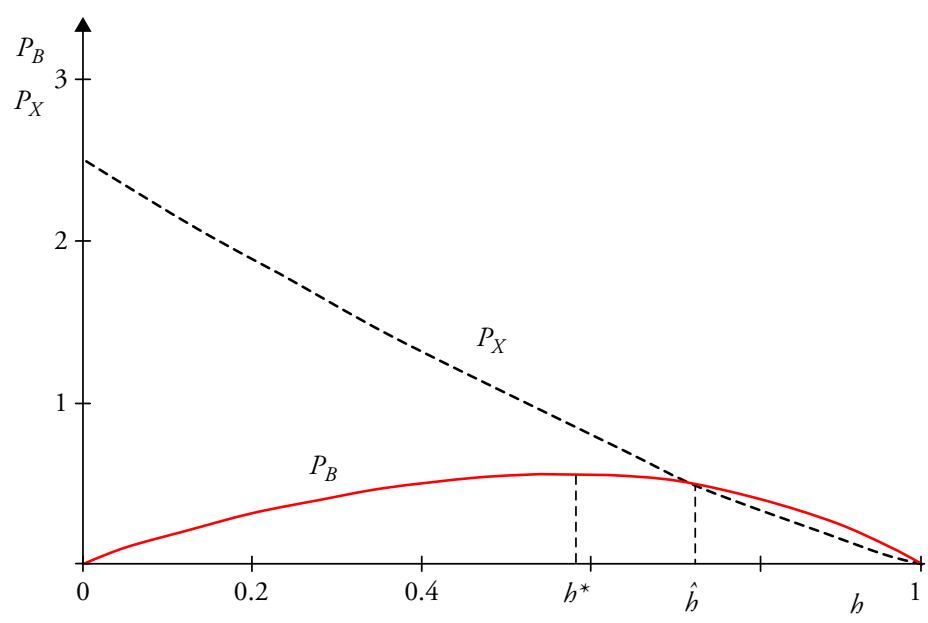

Figure 1 Sectoral profits depending on real unit labour costs

7. A second solution is located outside the interval $0<h<1$.

8. For $\left(1-t_{P}\right)\left(1-c_{P}\right)=\left(1-t_{W}\right)\left(1-c_{W}\right)$ the number $b^{*}$ converges to 0.5 , corresponding to a profit rate of 100 per cent. For details, see Helmedag (2012b; 2012c). It is shown in Appendix 1 that for the secondary sector no inner profit maximum exists, since its surplus always falls with increasing unit labour costs. 
operating in this division compensates for this difference. Eventually, given the assumed conditions depicted in Figure 1, the maximal gross profit of the basic sector and the corresponding unit labour costs $b^{*}$ should emerge.

Yet, depending on the underlying data, both profit functions can also intersect to the left of the profit maximum in the wage-good production. There, gains in both industries and the number of (equal) corporations coincide. Because more profit ensues, in that case unit labour costs settle down at $\hat{h}$, which is lower than $b^{*}$.

\section{EMPLOYMENT AND TECHNOLOGICAL PROGRESS}

At this point it is apposite to address similarities to and differences from a widespread model in post-Keynesian circles which was advanced by Bhaduri/Marglin (1990). They postulate vertically integrated production and mark-up pricing on (direct and indirect) labour costs, just as in the present exposition. Yet the authors assume exogenous real wage variations. In truth (and in this paper), however, these are the result rather than the starting point of the economic process. Bhaduri/Marglin argue that contingent upon behavioural reactions to changes in distribution, either workers' spending ('wage-led') or entrepreneurial investment expenses and export revenues ('profit-led') drive the system. The 'openness' of the approach is reflected by the contradictory empirical findings, which surely did not promote its applicability to economic policy. ${ }^{\text {? }}$

In a certain manner, the distinction in this study between a primary fabrication which produces the wage basket and a secondary industry, responsible for the rest of the supply, extends the Bhaduri-Marglin model. Though these researchers distinguish two groups of commodities serving either private consumption or private investment at the outset, this separation is not reflected in two analytically divided production spheres, let alone in the hierarchical relation between them.

Of course, in reality there are no representative bosses in the sectors who operate along known profit curves. In addition, the supposition of identical company sizes contradicts facts. Nevertheless, unit labour costs might tend towards the lower of two positive values, referring either to the intersection of the profit curves or to the basic sector's maximum profit.

Against this backdrop, it is a priori unclear which concrete level of real unit labour costs is targeted and, finally, comes out. Regardless, real-life wage-good manufacturers - entrepreneurs who sell primarily to employees - at least intuitively perceive that a 'mean' level of the profit rate is advantageous for them. Consequently, they will prevent unit labour costs from falling too low or rising too high. ${ }^{10}$

Gross national income $(Y)$ amounts to:

$$
\begin{aligned}
Y=(1+r)\left(W_{B}+W_{X}\right) & =\frac{(1+r) A}{r\left(1-c_{P}\right)\left(1-t_{P}\right)+\left(1-c_{W}\right)\left(1-t_{W}\right)}= \\
& =\frac{A}{(1-h)\left(1-c_{P}\right)\left(1-t_{P}\right)+b\left(1-c_{W}\right)\left(1-t_{W}\right)}
\end{aligned}
$$

9. Hein (2017) discusses alternatives to assign certain variables of the model an exogenous or an endogenous status.

10. For example, as of March 2017 the German retail store chain, Lidl, has raised the internal lowest hourly rate to $€ 12$, which is significantly above the country's statutory minimum wage (see https://www.lidl.de/de/faire-entlohnung/s7373177). Fairness considerations lead to a labour share in gross domestic product of approximately 61.8 per cent (see Helmedag 2010). 
Dividing the wage bill (11) by total earnings (16) gives $\left(W_{B}+W_{X}\right) / Y=h$, hence the functional income distribution fluctuates just as much as unit labour costs. But while the variation of this magnitude is positively correlated with staff emoluments, the effect on the domestic product is subject to the parameter condition:

$$
\frac{\partial Y}{\partial h} \leq 0 \text { for }\left(1-c_{P}\right)\left(1-t_{P}\right) \frac{\leq}{>}\left(1-c_{W}\right)\left(1-t_{W}\right) .
$$

Yet, if unit labour costs $h$ are given alongside the propensities to consume, ceteris paribus, economic activity increases at a steady production-price level with autonomous demand $A$ and fiscal charges $t_{W}$ and $t_{P} .{ }^{11} \mathrm{In}$ fact, these links put economic policy in a position to promote employment. But a deeper look behind the scenes yields even further insights.

In the present framework the volume of work $(N)$, that is, the quantity of labour hours per period of time - usually a year - is easily computed. One just has to divide national income $(Y)$ by the uniform hourly yield $(y)$ :

$$
N=\frac{Y}{y} \text {. }
$$

From equation (18) immediately follows the so-called 'scissors' tautology: Fluctuations in the volume of work arise from different rates of output changes on the collective and individual level, respectively:

$$
\frac{d N}{N}=\frac{d Y}{Y}-\frac{d y}{y}
$$

Therefore, total labour input per year rises if the macroeconomic growth rate - for example, due to the aforementioned measures - exceeds the microeconomic evolution. Consequently, unemployment can be diminished while individual working hours are kept constant. Yet the past was sometimes characterized by a reverse ranking of the influencing factors. Aggregate demand growth more often stayed behind the productivity increase that resulted from process innovations. Then the total number of labour hours shrinks, even if the 'golden wage rule' is fulfilled, that is, real unit labour costs remain stationary. As a result, shorter average individual working time is inevitable to avoid dismissals (see Helmedag 2016).

In addition, the effects of technological innovations in the basic industry principally differ from those in the luxury division. This aspect can be examined, however, only with a 'mesoeconomic' approach implementing an assignment of all products either to the primary or secondary sector. Of course, the ratio between the industries' wage bills (12) also holds for the relation of employment in the basic $\left(N_{B}\right)$ and in the profit $\left(N_{X}\right)$ industry. Therefore, the volume of work results in:

$$
N=N_{B}+N_{X}=\frac{h c_{W}\left(1-t_{W}\right)}{1-h c_{W}\left(1-t_{W}\right)} N_{X}+N_{X}=\frac{N_{X}}{1-h c_{W}\left(1-t_{W}\right)} .
$$

Notionally, the workforce in the surplus industry can be resolved into the quantity of virtual luxury goods $(X)$ times the embodied labour content in each object $\left(v_{X}\right) .{ }^{12}$

11. Since higher levies tend to enlarge the public sector at the expense of private business, politics has to decide on the taxable capacities.

12. The relative price of the secondary item $\left(p_{X}\right)$ expressed in the primary good $\left(p_{B}\right)$ coincides with the ratio of labour values: $p_{X} / p_{B}=v_{X} w_{B} p_{B}(1+r) / v_{B} w_{B} p_{B}(1+r)=v_{X} / v_{B}$. 
Furthermore, according to equation (3), unit labour costs $h$ conform to the value of labour power $v_{B} w_{B}$. The substitutions lead to:

$$
N=\frac{v_{X} X}{1-v_{B} w_{B} c_{W}\left(1-t_{W}\right)} .
$$

Thus, the connection between the volume of work and labour values is established. The alteration of employment emerges as the bottom line of varying determinants: ${ }^{13}$

$$
\frac{d N}{N}=\frac{d X}{X}+\frac{d v_{X}}{v_{X}}+\frac{v_{B} w_{B} c_{W}\left(1-t_{W}\right)}{1-v_{B} w_{B} c_{W}\left(1-t_{W}\right)}\left(\frac{d v_{B}}{v_{B}}+\frac{d w_{B}}{w_{B}}\right) .
$$

The first two fractions on the right-hand side of the 'motion equation' (22) reflect modifications in the surplus sector. If productivity rises in this division, the labour value per unit decreases, so the rate of change is negative: $d v_{X} / v_{X}<0$. If nothing else happens, technological progress in the luxury industry is completely mirrored in employment: The volume of work drops by the same percentage. As compensation, secondary output $X$ would have to increase accordingly. Hence, higher investments or more public spending are appropriate - means which always foster labour requirements in the presence of idle capacities.

From equation (3) and equation (12) it follows that the fraction preceding the brackets in equation (22) coincides with the relation between the sectoral wage bills $W_{B} / W_{X}$. Ceteris paribus, this weighting factor determines how the volume of work is affected: on the one hand negatively by a reduction in the basic products' labour value, and on the other hand positively through an increase in real wages. In case of constant unit labour costs that is, the rise in remuneration matches the productivity growth in the basic sector the terms in brackets cancel out. Then the dynamics of job opportunities only hinges on the quantity of luxuries compared to the productivity in their creation - an insight obtained by drawing on the labour theory of value. Yet other findings deserve emphasis, too.

\section{MARX AND KEYNES: SYNTHESIS CREATES SYNERGY}

The classical method to categorize output in either necessary or luxury goods has proven to be exceptionally fruitful. The founders of the discipline recognized the production of provisions for employees as the basis of the modern economy. To boot, they assumed substantially fixed subsistence remuneration. Based on this supposition, striking features of the system were revealed: Because input and output in the wage-good sector are homogeneous, a material rate of profit (or exploitation) can be ascertained by setting the amount of profit (or surplus) in relation to labour costs. In equilibrium, this ratio is adopted by the luxury sector which satisfies remnant demand. ${ }^{14}$ Therefore, a hierarchy between the primary and secondary industry exists.

But it is deceptive to identify the output of the basic sector with the worker's typical basket of goods, which allegedly represents their consumption behaviour. This approach leads us astray since there are many commodities bought more or less by wage and profit

13. The expression corresponds to the formula derived in a simpler framework, see Helmedag (2013a).

14. Alas, up to the present day, the dimensionless magnitude 'rate of profit' is habitually confused with a 'rate of return on investment' or a 'rate of interest', which always relate to a certain period of time, mostly a year. 
earners, not only the aforementioned toothpaste, but also salt, sugar, paper tissues, etc. After all, a physically interpreted subsistence level of employees is a far-fetched premise which does not push economic theory forward.

In order to escape from the impasse, the analysis has to focus on the financial origin of expenses. In a closed economy without any economic activity of the state, the two fundamental markets described at the beginning can be separated by their customers' sources of income. Revenues in the basic industry are paid out of wages whereas the luxury division receives proceeds financed by profits from entrepreneurial activities and wealth. In a more realistic model including international trade and the public sector, the primary segment $a b$ ovo manufactures commodities exclusively acquired by the workforce. The turnover of the similarly vertically integrated secondary division is paid with money which does not come from disposable total wages. Though this sector is called luxury, other than the delivery of consumption items bought with capital income, the surplus industry comprises autonomous investments, exports and public goods. Besides, it makes sense to express the respective output of both sectors in a distinctive, yet fictitious final product each representing a certain labour value.

The basic sphere determines - possibly in a trial-and-error process - the real unit labour costs and at the same time the general rate of profit, because, when no frictions occur, this percentage must be uniform throughout the economy. Furthermore, in the wage-good production, unit labour costs and the amount of gross profit do not always move in the same direction. Rather, gains in this division increase up to a certain point with employees' remuneration in the secondary sector, which benefits the basic industry's proceeds. Starting from zero, the gross margin in this sector rises with the value of labourpower - accompanied by a falling rate of profit - until either the maximum gain of the primary sector is reached or sectoral total profits coincide. Therefore, the wage-good fabrication displays in practice a more or less intuitively perceived interest in a sufficiently high emolument of staff. This explains why, in spite of decades of mass unemployment, unit labour costs have not hit rock bottom, but have settled somewhere in the mid-range (see Helmedag 2013b: 153). Obviously, business may also be made with workers' earnings! And of course, unit labour costs may swing in a certain range around the focal points $b^{*}$ or $\hat{h}$, as was observable in the past.

Viewed in this light, trade unions should not indulge in effusive hopes to enforce by mere wage improvements the individual and collective share of their clientele in national income. For this, the increment in real pay has to exceed the productivity growth in the basic industry. Furthermore, according to equation (22), rising unit labour costs entail, taken by themselves and subject to the weighting factor, a more or less pronounced surge in the volume of work. This leads, as equation (11) indicates (in contrast to popular opinion), to an augmented wage bill. The threat of reduced profits, however, induces employers in good time to put a stop to the workers' wishful thinking. At first, bosses in collective bargaining try to keep the redistribution component in the settlement as low as possible. If and when they do not succeed completely, entrepreneurs in step two have an effective remedy to neutralize excessive wage agreements: Higher prices thwart the workers' plans by preventing an increase in the purchasing power of pay.

If workers' associations nevertheless accomplish at least steady unit labour costs, the technological progress in the non-basic sector reduces, ceteris paribus, the volume of work equally. As an offset to this redundancy, a strengthening of autonomous demand or a vaster supply of public goods is needed. But as it stands, doubts remain as to whether the appropriate economic policy measures will be adopted, and to the necessary extent. Thus, in the foreseeable future, there is little chance of full employment and a reversal of the escalating concentration in income and wealth all over the globe (see Alvaredo et al. 2018). 
From this perspective, not only have Marx's and Keynes's analyses of capitalism proven highly complementary, but the essence of their statements cited at the outset regarding the serious deficits of the contemporary economic regime still (unfortunately) applies. And both pundits may agree to the view that it requires much more than mere cosmetic corrections of symptoms to effectuate a change from quantity into quality.

\section{REFERENCES}

Alvaredo, F., Chancel, L., Picketty, T., Saez, E., Zucman, E. (2018): World Inequality Report, URL: wir2018.wid.world.

Bhaduri, A., Marglin, St. (1990): Unemployment and the real wage: the economic basis for contesting political ideologies, in: Cambridge Journal of Economics, 14, 375-393.

Hein, E. (2017): The Bhaduri-Marglin post-Kaleckian model in the history of distribution and growth theories: an assessment by means of model closures, in: Review of Keynesian Economics, $5,218-238$.

Helmedag, F. (2010): Fair wages and social welfare, in: Journal of Income Distribution, 19, 3-8.

Helmedag, F. (2012a): Die Beschäftigungstheorie von Keynes: Dichtung und Wahrheit, in: Busch, U. (ed.), Jenseits der Orthodoxie, Ansätze für einen Paradigmenwechsel in der Wirtschaftstheorie, Berliner Debatte Initial, 23, 63-76.

Helmedag, F. (2012b): Principles of capitalistic commodity production, in: European Journal of Economics and Economic Policies: Intervention, 9, 23-34.

Helmedag, F. (2012c): Kapitalistischer Kommunismus, in: Ökonomie und Gesellschaft, Jahrbuch 24: Entfremdung - Ausbeutung - Revolte, Karl Marx neu verhandelt, Marburg: Metropolis, 111-126.

Helmedag, F. (2013a): Principles of capitalistic commodity production: a rejoinder, in: European Journal of Economics and Economic Policies: Intervention, 10, 282-285.

Helmedag, F. (2013b): Möglichkeiten und Grenzen einer beschäftigungsfördernden Lohnpolitik, in: Kromphardt, J. (ed.), Zur aktuellen Finanz-, Wirtschafts- und Schuldenkrise, Schriften der KeynesGesellschaft, Bd. 6, Marburg: Metropolis, 145-158.

Helmedag, F. (2014): Über Kapital im 'Kapital': Einige elementare Überlegungen, in: Wirtschaft und Gesellschaft, 40, 405-415.

Helmedag, F. 2016: Nur mehr Stundenlohn oder auch weniger Arbeitsstunden? Gewerkschaftsforderungen im Widerstreit, in: Hagemann, H., Kromphardt, J. (eds), Keynes, Schumpeter und die Zukunft der entwickelten kapitalistischen Volkswirtschaften, Schriften der Keynes-Gesellschaft, Bd. 9, Marburg: Metropolis, 273-287.

Helmedag, F. (2018): Warenproduktion mittels Arbeit, Zur Rehabilitation des Wertgesetzes, 3. Aufl., Marburg: Metropolis.

Keynes, J.M. (1930 [1972]): Economic possibilities for our grandchildren, in: The Collected Writings of John Maynard Keynes, Vol. IX, Essays in Persuasion, London and Basingstoke, UK: Macmillan and Cambridge University Press, 321-332.

Keynes, J.M. (1936 [1973]): The General Theory of Employment, Interest and Money, London and Basingstoke, UK: Macmillan and Cambridge University Press.

Marx, K. (1867 [1977]), Das Kapital, Erster Band, Der Produktionsprozess des Kapitals, Marx Engels Werke, Bd. 23, Berlin: Dietz.

Pigou, A.C. (1933 [1968]): The Theory of Unemployment, London: Frank Cass.

Ricardo, D. (1815 [1951]): An essay on the influence of a low price of corn on the profits of stock, in: Sraffa, P. (ed), The Works and Correspondence of David Ricardo, Vol. IV, Cambridge, UK: Cambridge University Press, 9-41.

Smith, A. (1776 [1981]): An Inquiry into the Nature and Causes of the Wealth of Nations, Vol. I, Indianapolis: Liberty Classics. 


\section{APPENDIX 1}

In footnote 8 it was reported that the profit of the luxury division $P_{X}$ decreases with rising unit labour costs. In order to verify this statement, the positive correlation between the sector's gain and the rate of profit is proven. From equation (10) ensues:

$$
\begin{aligned}
P_{X}=r W_{X} & =\frac{r\left(r+1-c_{W}\left(1-t_{W}\right)\right) A}{(1+r)\left[r\left(1-c_{P}\right)\left(1-t_{P}\right)+\left(1-c_{W}\right)\left(1-t_{W}\right)\right]}= \\
& =\frac{\left(r^{2}+r a\right) A}{r \alpha_{P}+\alpha_{W}+r^{2} \alpha_{P}+r \alpha_{W}} .
\end{aligned}
$$

In the second fraction the abbreviations below have been used:

$$
\begin{aligned}
& 0<a \equiv 1-c_{W}\left(1-t_{W}\right)<1 \\
& 0<\alpha_{P} \equiv\left(1-c_{P}\right)\left(1-t_{p}\right)<1 \\
& 0<\alpha_{W} \equiv\left(1-c_{W}\right)\left(1-t_{W}\right)<1 .
\end{aligned}
$$

The partial derivative of $P_{X}$ with respect to the rate of profit $r$ can be written as:

$$
\frac{\partial P_{X}}{\partial r}=\frac{A\left(Z_{1}+Z_{2}\right)}{(\cdot)^{2}} .
$$

The symbols $Z_{1}$ and $Z_{2}$ stand for:

$$
\begin{aligned}
& Z_{1}=2 r^{2} \alpha_{P}+2 r \alpha_{W}+2 r^{3} \alpha_{P}+2 r^{2} \alpha_{W}+a r \alpha_{P}+a \alpha_{W}+a r^{2} \alpha_{P}+a r \alpha_{W} \\
& Z_{2}=-\left(r^{2} \alpha_{P}+2 r^{3} \alpha_{P}+r^{2} \alpha_{W}+a r \alpha_{P}+2 a r^{2} \alpha_{P}+a r \alpha_{W}\right) .
\end{aligned}
$$

Since $0<a<1$, the sum of $Z_{1}$ and $Z_{2}$ is positive:

$$
Z_{1}+Z_{2}=r^{2} \alpha_{P}(1-a)+\alpha_{W}(r(r+2)+a)>0 .
$$

Thus, according to (A2), the gain in the secondary industry always moves in the same direction as the rate of profit or varies inversely with unit labour costs. Consequently, only the basic industry exhibits an interior profit maximum.

q. e. d. 